\title{
Transformation and Transposon Mutagenesis of Leifsonia xyli subsp. xyli, Causal Organism of Ratoon Stunting Disease of Sugarcane
}

\author{
Stevens M. Brumbley, ${ }^{1,5}$ Lars A. Petrasovits, ${ }^{2}$ Robert G. Birch, ${ }^{3}$ and Paul W. J. Taylor ${ }^{4}$ \\ ${ }^{1}$ Bureau of Sugar Experiment Stations, 50 Meiers Rd., Indooroopilly, Queensland, Australia 4068; ${ }^{2}$ Department of \\ Chemical Engineering, University of Queensland, St. Lucia, Australia 4072; ${ }^{3}$ Department of Botany, University of \\ Queensland, St. Lucia, Australia 4072; ${ }^{4}$ Joint Center for Crop Improvement, University of Melbourne, Parkville, Victoria, \\ Australia 3052; ${ }^{5}$ Cooperative Research Centre for Tropical Plant Protection, University of Queensland, Brisbane, \\ Australia 4072
}

Submitted 3 April 2001. Accepted 3 December 2001.

Conditions have been developed for genetic transformation and insertional mutagenesis in Leifsonia xyli subsp. xyli (Lxx), the causal organism of ratoon stunting disease (RSD), one of the most damaging and intractable diseases of sugarcane internationally. Transformation frequencies ranged from 1 to 10 colony forming units (CFU)/ $\mu \mathrm{g}$ of plasmid DNA using Clavibacter/Escherichia coli shuttle vectors pCG188, pDM302, and pDM306 and ranged from 50 to 500 $\mathrm{CFU} / \mu \mathrm{g}$ using cosmid cloning vectors pLAFR3 and pLAFR5-km. The transformation/transposition frequency was 0 to $70 \mathrm{CFU} / \mu \mathrm{g}$ of $\mathrm{DNA}$, using suicide vectors pUCD623 and pSUP2021 containing transposable elements Tn4431 and Tn5, respectively. It was necessary to grow Lxx in media containing $0.1 \%$ glycine for electroporation and to amplify large plasmids in a $\mathrm{dam}^{-} / \mathrm{dcm}^{-} \mathrm{E}$. coli strain and purify the DNA by anion exchange. To keep selection pressure at an optimum, the transformants were grown on nitrocellulose filters $(0.2-\mu \mathrm{m}$ pore size) on media containing the appropriate antibiotics. Transposon Tn4431 containing a promoterless lux operon from Vibrio fischeri and a tetracycline-resistance gene was introduced on the suicide vector pUCD623. All but $1 \%$ of the putative transposon mutants produce light, indicating transposition into functional Lxx genes. Southern blot analysis of these transformants indicates predominantly single transposon insertions at unique sites. The cosmid cloning vector pLAFR5-km was stably maintained in Lxx. The development of a transformation and transposon mutagenesis system opens the way for molecular analysis of pathogenicity determinants in Lxx.

Ratoon stunting disease (RSD) caused by Leifsonia xyli subsp. xyli (Lxx) (Evtushenko et al. 2000), previously called Clavibacter xyli subsp. xyli (Davis et al. 1984), is one of the most widespread diseases of sugarcane (Gillaspie and Teakle 1989; Hughes 1974), resulting in up to $30 \%$ crop losses under drought stress conditions. RSD is difficult to detect in the field because stunting can be caused by a range of environmental factors and there are no reliable external symptoms of Lxx infection (Gillaspie and Teakle 1989). It remains one of the most economically important diseases of sugarcane, even in coun-

Corresponding author: S. M. Brumbley; E-mail: sbrumbley@bses.org.au tries where integrated disease control practices have been in place for over 40 years (Croft and Smith 1995).

Sugarcane is vegetatively propagated. After harvesting the above-ground portion of the plant crop, multiple additional harvests (ratoons) may be achieved, depending on environmental conditions, harvesting techniques, and disease pressure. Because RSD is spread mechanically by planting, cultivating, and harvesting equipment, as well as by infected plant material (Taylor et al. 1988), it is essential that the initial planting material be free of RSD. A common practice for the control of RSD is to treat sugarcane planting material with hot water at $50^{\circ} \mathrm{C}$ for 2 to $3 \mathrm{~h}$ before establishing seedcane nurseries (Steindl 1974). This approach has several disadvantages including incomplete eradication when heavily infected cane is treated (Roach 1987), a requirement for expensive equipment and staff time, poor germination of some cultivars after heat treatment (Victoria et al. 1986), and an increased susceptibility of some varieties to sugarcane smut after treatment (Bailey 1977). There are RSD-resistant sugarcane varieties (Croft and Greet 1997; Comstock et al. 1998), but it is a difficult trait to assess, and no routine breeding program has added screening for RSD resistance to its list of selected traits.

The pathogen Lxx is a small coryneform, gram-positive bacterium that colonizes the xylem vessels of sugarcane plants. Stunting is believed to be caused by plugging of the xylem vessels (Gillaspie et al. 1973; Maramorosch et al. 1973; Teakle et al. 1973), but it is not known whether the gelatinous plug is produced by Lxx or sugarcane. Lxx is nutritionally fastidious and is extremely slow growing on solid medium (Davis 1980). These experimental difficulties have delayed investigation of the physiological and molecular basis of pathogenicity or disease resistance. However, recent progress with genetic transformation of other coryneform phytopathogens (Metzler et al. 1992; Lampel et al. 1994; Meletzus et al. 1993; Schäfer et al. 1990; Taylor et al. 1993), including Leifsonia xyli subsp. cynodontis (Evtushenko et al. 2000; Suzuki et al. 1999), previously called Clavibacter xyli subsp. cynodontis (Davis et al. 1984), a fast growing relative of Lxx that causes a stunting disease of Bermuda grass, indicates the possibility for molecular genetic analysis of RSD. Here, we report the first successful transformation of Lxx and demonstrate transposon mutagenesis opening the way for molecular genetic analysis in this major phytopathogen of sugarcane. 


\section{RESULTS}

Transformation of Lxx.

A range of modifications to the culture media, the plasmid purification method, growth conditions on solid media after transformation, and even the bacterial strain used to amplify the plasmid DNA had to be tried before a routine transformation system was developed for Lxx. After over 200 attempts to transform Lxx by electroporation using cuvettes with gaps from 0.1 or $0.2 \mathrm{~cm}$, varying the voltage from 1.0 to $2.5 \mathrm{kV}$ with a resistance of $100 \Omega$ and a capacitance of $125 \mu \mathrm{F}$, and using a range of $\mathrm{CsCl}$ purified plasmids (Sambrook et al. 1989) including pCG188, pDM302, pDM306, pLAFR3, and pLUX19, only four plates were observed to have antibiotic resistant colonies. Of these four plates, three had one colony each and one plate had two colonies. All five of these colonies failed to grow after restreaking on fresh antibiotic-containing medium. No spontaneous antibiotic-resistant mutants were ever observed to grow in any of the routine controls where $1 \times 10^{7}$ to $1 \times 10^{10}$ colony forming units (CFU) of untransformed Lxx or Lxx electroporated with no added plasmid DNA were plated on the relative antibiotic selection media.

Transformation of Lxx was successful only after glycine $(0.1 \% \mathrm{wt} / \mathrm{vol})$ was added to the liquid culture media as part of the filter-sterilized component. The $0.1 \%$ (wt/vol) concentration of glycine was chosen because it slowed growth of Lxx by $50 \%$, whereas concentrations less than or equal to $0.05 \%$ (wt/vol) had no perceptible effect on growth, and concentrations greater than $0.1 \%$ (wt/vol) completely inhibited growth. Routine transformation, especially with large plasmids such as pUCD623 (47 $\mathrm{kb}$ ), was not achieved until the plasmids were amplified in the methylation- and restriction-defective E. coli strain GM2163 and were purified using anion exchange columns. Using these conditions, Lxx was transformed with pDM302, pDM306, pCG188, pUCD623, pLAFR3, pLAFRLUC, pLAFR5-km, and pLUX19, evidenced by antibiotic resistance and confirmed by polymerase chain reaction (PCR) analysis (Fig. 1A and B), reisolation of plasmid DNA (data not shown), Southern blot analysis (Fig. 2), or expression of the marker genes (data not shown). The cosmid cloning vectors pLAFR3 and pLAFR5-km (Table 1) gave the highest transformation efficiency (100 to $500 \mathrm{CFU} / \mu \mathrm{g}$ of plasmid DNA). No significant difference in transformation efficiency was found between Lxx strains.

\section{PCR analysis and stability studies of Lxx transformants.}

The presence of pDM302, pDM306, and pLUX19 (Fig. 1A and B) were all confirmed by PCR. In some of the putative transformants, the antibiotic resistance gene of the plasmid was not detected by PCR (Fig. 1B; lanes 2B, D, E, F, and 6F) and

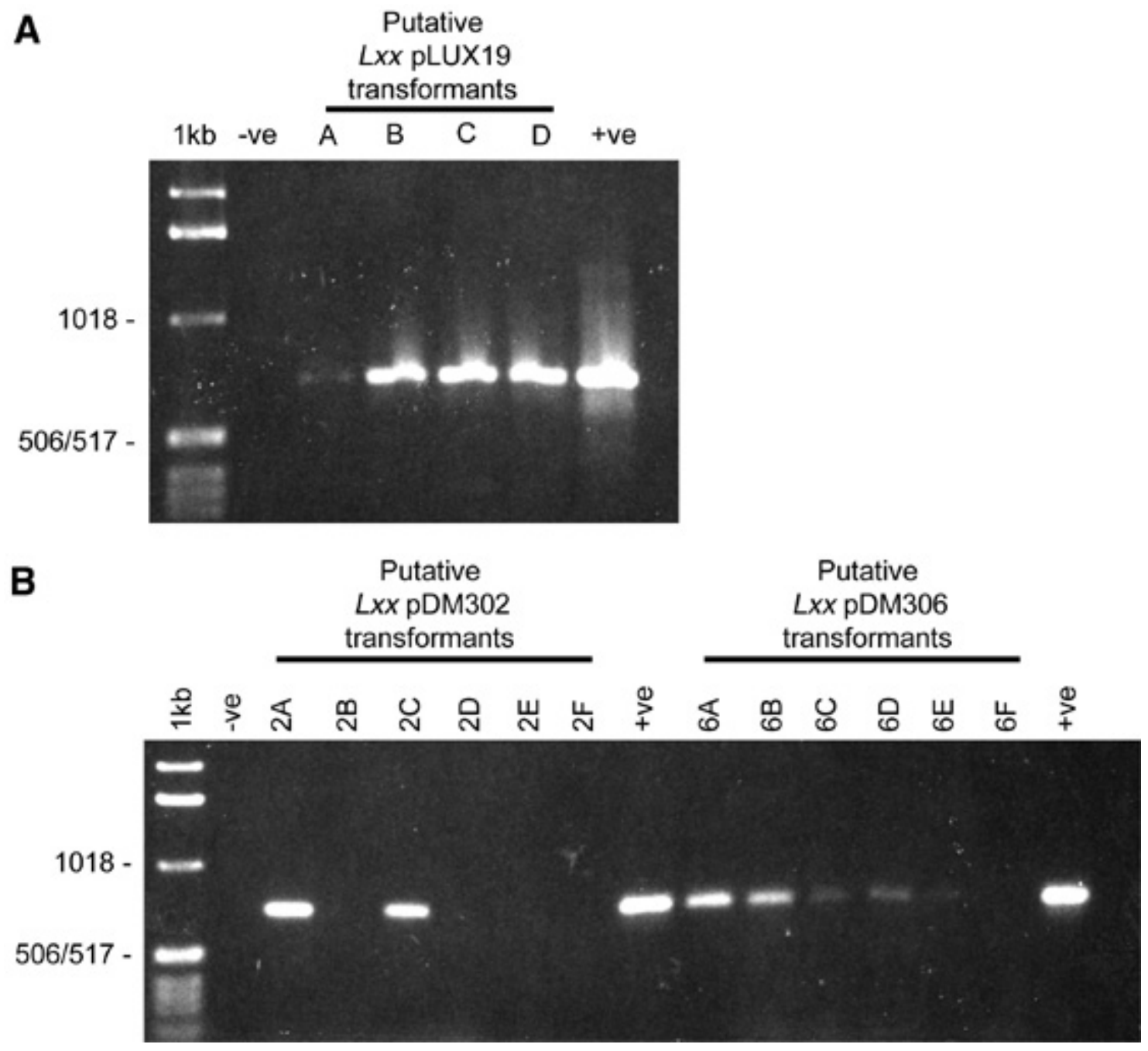

Fig. 1. A, Polymerase chain reaction (PCR) analysis using the nptII primer set on Leifsonia xyli subsp. xyli (Lxx) isolates transformed with pLUX19. The negative control (-ve) included DNA from wild-type Lxx isolate QPF110-108. The positive control (+ve) template was 0.5 ng of pLUX19. B, PCR analysis using the nptII primers on Lxx isolates transformed with pDM302 and pDM306. The negative control reaction included DNA from wild-type Lxx isolate QPF110-108. The positive control templates were $0.5 \mathrm{ng}$ of pDM302 and pDM306, respectively. 
those colonies failed to grow when restreaked on fresh antibiotic-containing medium. Plasmids (pLAFR3, pLAFR5-km, pLAFRLUC, and pLUX19) were reisolated from 12 Lxx transformants and were found by restriction digest analysis to be identical, further demonstrating the stability of these vectors (data not shown). pSUP2021 transformants were found to be stable for $\mathrm{Km}^{\mathrm{r}}$ (Table 2), but the presence of the plasmid or the transposon was never detectable in these transformants by PCR, Southern blot analysis, or plasmid isolation. We were unable to determine why these putative transformants were able to grow on kanamycin-containing medium, considering that the negative controls, Lxx cells electroporated without pSUP2021, never produced colonies on media containing kanamycin.

Stability of pLAFRLUC transformants ranged from 26 to $100 \%$ antibiotic-resistant colonies after 4 weeks of growth without antibiotics (Table 2). pLUX19 transformants ranged from 0 to $60 \%$ antibiotic-resistant colonies (Table 2). The Lxx transformants containing pDM302 and pDM306 were highly unstable (data not shown). Only a small number of transformants was ever detected and from these, all but one of the colonies of each subculture failed to regrow when restreaked onto fresh selection media containing kanamycin.

\section{Transposon mutagenesis of $\mathbf{L x x}$.}

Of six tested Lxx pUCD623 transformants, five were stable for antibiotic resistance after 4 weeks without antibiotic selection (Table 3). One transformant segregated 42 positive colonies out of 50 tested (Table 3 ). In addition, these transformants were tested for light production from the lux operon encoded in the transposon, and most of them produced light without the addition of substrate (Table 3). The absence of the suicide vector (pUCD623) was demonstrated by PCR analysis of 12 Lxx::Tn4431 mutants, using primers specific to the ampicillin and chloramphenicol marker genes, both located outside of Tn4431 on pUCD623 (data not shown).

Southern analysis using total genomic DNA isolated from 30 tetracycline-resistant Lxx transformants generated by electroporation with pUCD623 showed Tn4431 on different-sized restriction fragments, indicating transposition into the genome of Lxx. The smallest fragment expected would be just over $4.26 \mathrm{~kb}$, because the probe was isolated from the end of the transposon. Results of one Southern analysis using 20 of the Lxx::Tn4431 insertion mutants is shown in Figure 2. Of 30 Lxx::Tn4431 mutants tested by Southern analysis, only one had a double insertion; the rest had single site insertions (data not shown). The highest number of transposon mutants generated from a given transformation experiment was 32 per $\mu \mathrm{g}$ of pUCD623, and the mean of 10 consecutive electroporations was 17.6 mutants per $\mu \mathrm{g}$.

\section{Light production.}

The lux operon on Tn4431 includes a gene for Lux substrate biosynthesis, but light production can be enhanced with additional substrate (n-decyl aldehyde). Of 750 Lxx::Tn4431 mutants, light production from 743 mutants was detected by low-light camera or scintillation counter (data not shown). The light intensity varied between mutants and was enhanced by the addition of n-decyl aldehyde, except for seven mutants that produced no light.

\section{DISCUSSION}

The tools of molecular genetics have proven to be very powerful for the analysis of pathogenicity mechanisms in gramnegative bacterial plant pathogens. In order for this approach to be applied for gram-positive phytopathogens such as Lxx, it was first necessary to develop transformation tools and systems for generating mutants. Lxx is a nutritionally fastidious phytopathogen, but it can be cultured reliably on M-SC (Teakle and Ryan 1992) medium. We adapted this medium with a higher agar concentration to allow streaking for single colonies, and plating cells on a membrane allows the subculture of slow-growing colonies on fresh antibiotic-containing medium to maintain selection pressure.

Because no native plasmids were detected in any of the Lxx isolates tested, it was decided to test constructs that had been developed for other Clavibacter species (pCG188, pDM302 and pDM306), that would be useful for library construction and had been shown to be semistably maintained in Leifsonia xyli subsp. cynodontis (pLAFR3) (Metzler et al. 1992), that had useful detectable markers (pLUX19, pLAFRLUC), or that contained a transposable element for mutagenesis (pSUP2021 or pUCD623).

Routine transformation of Lxx was achieved by combining the following elements: the addition of $0.1 \%$ (wt/vol) glycine to the Lxx culture medium, amplification of the vectors in an $E$. coli strain defective in the dam and $\mathrm{dcm}$ methylation systems, and the purification of high quality plasmid DNA using anion exchange columns. The addition of $0.1 \%$ (wt/vol) gly-

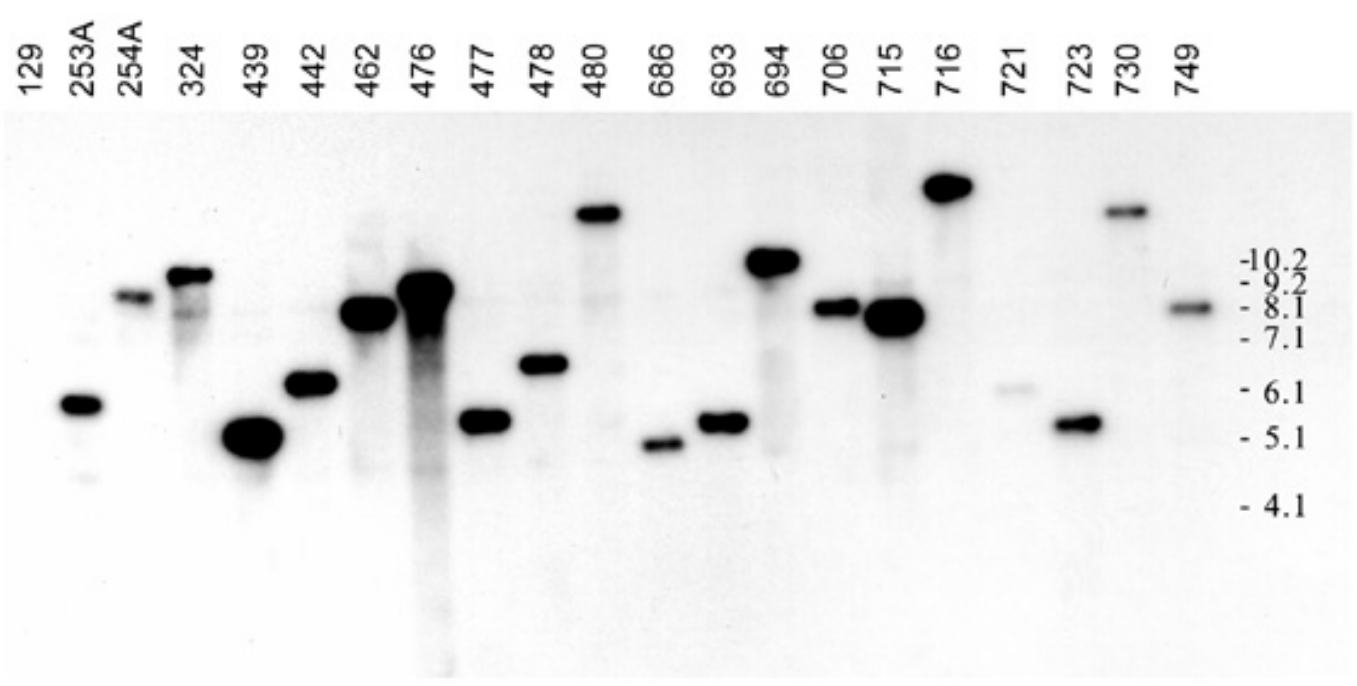

Fig. 2. Southern analysis of genomic DNA from Lxx::Tn4431 mutants digested with PstI and probed with a 4.26-kb EcoRI/PstI fragment from the 5' (transposase) end of Tn4431. Lane1 is wild-type Leifsonia xyli subsp. xyli isolate QPF835-129. Each of the other lanes is from a transposon mutant from separate electroporations, except for 693 and 694 and 715 and 716, for which two separate colonies were taken per electroporation. 
cine slowed growth of Lxx in liquid culture by $50 \%$ and is believed to interfere with bacterial cell wall assembly, thereby making it easier to get the plasmid DNA through the tough gram-positive cell wall. Gram-positive coryneform bacteria have methylation and restriction systems different from those of gram-negative bacteria (Vertès et al. 1993). The elimination of the dam and $\mathrm{dcm}$ methylation and the use of high quality plasmid preps was essential for transformation using large plasmids (pUCD623). With these modifications, the transformation efficiencies ranged from 0 to 32 colonies for pUCD623 and ranged from 200 to 500 colonies for pLAFR3 and pLAFR5-km.

One of the key successes of this work was the establishment of pUCD623 as a vector for transposon mutagenesis. pUCD623 has the complete lux operon from Vibrio fischeri, minus a promoter, and a tetracycline-resistance gene all encoded in the transposable element Tn4431 (Shaw et al. 1988). This opens the way for transposon mutagenesis and genetic analysis of pathogenicity in Lxx. Although the efficiency of transposition is too low for saturation mutagenesis in Lxx, it should be sufficient for pathogenicity studies if Lxx has large numbers of genes involved in bacterial pathogenicity, as is seen in many of the gram-negative phytopathogens. In addition, because the lux operon is promoterless, the transposon functions as a promoter probe and may be very useful for studying gene regulation during the interaction of Lxx with sugarcane. However, the low number of nonlight-producing Lxx transposon mutant $7 / 750$ and the fact that we were unable to detect glowing Lxx cells in plant tissue (data not shown) with the low-light ccd camera, coupled with the nutritionally fastidious nature of Lxx, may indicate a problem with using this transposon as a promoter probe.

Two possible reasons for the high number of transposon mutants producing light may be that the vector (pUCD623) is being stably maintained in Lxx or that there are one or more promoters in the transposon just before the start of luxC. PCR analysis of a selection of transposon mutants using primers to two antibiotic resistance genes, ampicillin and chloramphenicol, both of which are encoded outside of Tn4431 on pUCD623, clearly demonstrated that the vector is absent in these mutants. Sequence analysis of the region from the inverted repeat at the end of the transposon to the beginning of $\operatorname{lux} \mathrm{C}$ at the $5^{\prime}$ end of the operon revealed two putative promoter regions, one from bp 216..ggacgctacttgtgtataagagtcaggtataaaggtattctaagtcttcg..265 and the other from bp 295 .. gggacttagttgtagaaaataaccttgaatcagatgagtatgataactca..344, each with a 0.98 probability of being promoters, and both oriented correctly to drive transcription of the lux operon. The former promoter overlaps a putative remnant of the lux I gene that may have been left over from cloning the lux operon into Tn4431, and the latter promoter is in luxI. However, expression from either of these putative promoters does not explain the differential in levels of light produced by the various mutants or the mutants that produce no light at all. A third possibility would be that multiple transpositions had occurred in each mutant, but this is not backed up by the Southern blot analysis, which showed that only one of thirty transposon mutants tested had more than one insertion (data not shown).

Another important accomplishment was the development of pLAFR5-km for future construction of a Lxx wild-type cosmid strain library. This vector not only consistently gave the best transformation frequencies of the plasmids tested but also was highly stable, even in the absence of antibiotic selection pressure, indicating that complementation studies of key transposon mutants will be possible. For this purpose, the cosmid vector pLAFR5 (Keen et al. 1988) was modified by replacing the tetracycline-resistant marker with a kanamycin-resistant marker. The resulting vector, pLAFR5-km, retains the double cos sites for efficient packaging into phage heads. Transformation of Lxx::Tn4431 mutants for future complementation studies should not be hindered by the size of the cosmid clones (45 to $50 \mathrm{~kb}$ ), as evidenced by the ability to transform Lxx with pUCD623 (47 kb).

This study has established the basic tools for molecular dissection of pathogenicity in Lxx and generated a set of 750 independent transposon mutants. These tools may also be adapted to work on other nutritionally fastidious, slow-growing bacterial pathogens, particularly the other high $\mathrm{G}+\mathrm{C}$ coryneform phytopathogens.

\section{MATERIALS AND METHODS}

\section{Bacterial strains and cultures.}

Four unique Lxx isolates (QPF110, QPF153N, QPF83S, and ROY1) collected from different locations and sugarcane varieties were used to generate the transposon mutants. QPF110, QPF153, and QPF83S were isolated from infected sugarcane varieties Q110, Q153, and 83S1236, respectively, all growing at the Bureau of Sugar Experiment Stations Pathology farm at Eight Mile Plains, Queensland (QLD), Australia. Variety Q110 was inoculated with Lxx and maintained as the source plant for inoculation studies at the pathology farm, whereas varieties

Table 1. Plasmids

\begin{tabular}{|c|c|c|c|}
\hline Plasmid & Relevant characteristics $^{\mathrm{a}}$ & $\begin{array}{l}\text { Transformation efficiency } \\
(\text { CFU of DNA per } \mu \mathrm{g})^{\mathbf{b}}\end{array}$ & Source or reference \\
\hline pDM302 & $\mathrm{Cmm} / E$. coli shuttle vector; $14 \mathrm{~kb}$; ColE1 and native $\mathrm{Cmm}$ Ori; $\mathrm{Km}^{\mathrm{r}}, \mathrm{Cm}^{\mathrm{r}}$ & $1-5$ & Meletzus et al. 1993 \\
\hline pDM306 & $\mathrm{Cmm} / E$. coli shuttle vector; $13.6 \mathrm{~kb}$; ColE1 and native $\mathrm{Cmm}$ Ori; $\mathrm{Km}^{\mathrm{r}}, \mathrm{Gm}^{\mathrm{r}}$ & $1-5$ & Meletzus et al. 1993 \\
\hline pCG188 & Lxc/E. coli shuttle vector; $11 \mathrm{~kb}$; ColE1 and native $\mathrm{Lxc}$ Ori; $\mathrm{Ap}^{\mathrm{r}}, \mathrm{Cm}^{\mathrm{r}}$ & $1-9$ & Taylor et al. 1993 \\
\hline pUCD623 & $\begin{array}{l}\text { Tn } 4431 \text { containing promoterless lux operon from Vibrio fischeri on } \mathrm{pSa} 325 \\
\text { suicide vector; } 43 \mathrm{~kb} \text {; ColE1 Ori; } \mathrm{Ap}^{\mathrm{r}}, \mathrm{Cm}^{\mathrm{r}}, \mathrm{Tc}^{\mathrm{r}}\end{array}$ & $0-32$ & Shaw et al. 1988 \\
\hline pSUP2021 & Suicide vector containing Tn5; $11.7 \mathrm{~kb}$; ColE1 Ori; $\mathrm{Ap}^{\mathrm{r}}, \mathrm{Cm}^{\mathrm{r}}, \mathrm{Km}^{\mathrm{r}}$ & $10-70$ & Simon et al. 1983 \\
\hline pLAFR3 & Broad-host range cosmid cloning vector; $21.7 \mathrm{~kb}$; RP4 Ori; Tc ${ }^{\mathrm{r}}$ & $120-200$ & Staskawicz et al. 1987 \\
\hline pLAFRLUC & $\begin{array}{l}\text { Firefly luc gene from pLUC19 inserted into the BamHI site of pLAFR3; } \\
23.7 \mathrm{~kb} \text { : RP4 Ori; } \mathrm{Tc}^{\mathrm{r}}\end{array}$ & 50 & This study \\
\hline pLAFR5 & Improved broad-host range cosmid cloning vector; $21.5 \mathrm{~kb} ; \mathrm{RP} 4 \mathrm{Ori} ; \mathrm{Tc}^{\mathrm{r}}$ & $\mathrm{N} / \mathrm{t}$ & Keen et al. 1988 \\
\hline pLAFR5-km & Improved broad-host range cosmid cloning vector; $22.7 \mathrm{~kb}$; RP4 Ori; $\mathrm{Km}^{\mathrm{r}}$ & $50-500$ & This study \\
\hline pLUC19 & Firefly luc in pBIN19; $14.3 \mathrm{~kb}$; RK2 wide host-range Ori; $\mathrm{Km}^{\mathrm{r}}$ & $\mathrm{N} / \mathrm{t}$ & Mudge et al. 1996 \\
\hline pLUX19 & $\begin{array}{l}\text { Vibrio harveyi luciferase (lux } \mathrm{AB}) \text { fusion driven by lac promoter, in pBIN19; } \\
12.5 \mathrm{~kb} ; \mathrm{RK} 2 \text { wide host-range Ori; } \mathrm{Km}^{\mathrm{r}}\end{array}$ & $120-180$ & Mudge et al. 1996 \\
\hline
\end{tabular}


Q153 and 83S1236 were grown from RSD-infected sugarcane sets from Maryborough, QLD, and Nambour, QLD, respectively. ROY1 was isolated directly from an RSD-infected stalk of sugarcane from Bundaberg, QLD.

Lxx strains were isolated from infected sugarcane stalks by using pressurized air to express xylem fluid and then streaking the filtered $(0.45 \mu \mathrm{m})$ fluid onto M-SC medium (Teakle and Ryan 1992) with added bacto agar (4 g/l) and nalidixic acid (20 $\mu \mathrm{g} / \mathrm{ml})$ and increased glucose $(2 \mathrm{~g} / \mathrm{l})$. All isolates were confirmed to be Lxx by Southern blot analysis and PCR, using Leifsonia and Lxx specific primers (S. M. Brumbley, L. A. Petrasovits, R. G. Birch, and P. W. J. Taylor, unpublished data). Broth cultures were grown in S8 medium (Davis 1980) with the following modifications: $\mathrm{KH}_{2} \mathrm{PO}_{4}$ was increased to $1.10 \mathrm{~g} / \mathrm{l}, \mathrm{K}_{2} \mathrm{HPO}_{4}$ was decreased to $0.35 \mathrm{~g} / \mathrm{l}$, and in the filtered component, sucrose was increased to $2 \mathrm{~g} / \mathrm{l}$ and cysteine was decreased to $0.5 \mathrm{~g} / \mathrm{l}$. For genomic DNA isolation and electroporation, Lxx was grown in S8 broth containing 0.05 or $0.1 \%$ (wt/vol) glycine, respectively (Haynes and Britz 1989).

\section{DNA manipulation and hybridization.}

High-molecular weight DNA was obtained from Lxx as described by Lampel and associates (1994), except that egg white lysozyme was increased from $2 \mathrm{mg}$ per $\mathrm{ml}$ to $10 \mathrm{mg}$ per $\mathrm{ml}$ in the lysis buffer. The plasmids used in this study (Table 1) were amplified in E. coli strain GM2163 (New England Biolabs, Beverly, MA, U.S.A.), which is defective in both the dam and $\mathrm{dcm}$ methylation systems. Plasmid DNA for Lxx transformation was isolated from $E$. coli by alkaline lysis and anion exchange columns (Plasmid Maxi Kit; Qiagen Pty. Ltd., Hilden, Germany). Plasmid DNA from Lxx was isolated by alkaline lysis and phenol/chloroform extraction (Sambrook et al. 1989).

DNA probes for hybridization analysis of Lxx transposon mutants were radioactively labeled with $\left[\alpha-{ }^{32} \mathrm{P}\right] \mathrm{dCTP}$ (NEN Research, Boston, MN, U.S.A.) using the Rediprime oligolabeling kit (Amersham Pharmacia Biotech, Piscataway, NJ, U.S.A.). Southern analysis of DNA transferred from agarose gels to nylon membranes (Hybond N+; Amersham Pharmacia Biotech) was performed as described by D'Hont and associates (1994).

\section{Construction of pLAFR5-km.}

There are two SalI sites in pLAFR5, one in the polylinker and the other in the tetracycline-resistance gene. To generate pLAFR5-km, a $\mathrm{Km}^{\mathrm{r}}$ cassette (GenBlock [EcoRI] AMRAD; Amersham Pharmacia Biotech) was inserted into partially SalIdigested pLAFR5. Constructs that were kanamycin resistant

Table 2. Stability of Leifsonia xyli subsp. xyli transformants ${ }^{\mathrm{a}}$

\begin{tabular}{llc}
\hline Strain & Plasmid & \% Antibiotic $^{\mathbf{r}}$ colonies \\
\hline 874 & pSUP2021 & 92 \\
116 & pLUX19 & 0 \\
117 & pLUX19 & 16 \\
120 & pLUX19 & 40 \\
121 & pLUX19 & 26 \\
122 & pLUX19 & 60 \\
130 & pLAFRLUC & 100 \\
131 & pLAFRLUC & 100 \\
132 & pLAFRLUC & 100 \\
156 & pLAFRLUC & 46 \\
157 & pLAFRLUC & 58 \\
158 & pLAFRLUC & 78 \\
1032 & pLAFR5-km & 100 \\
\hline
\end{tabular}

${ }^{\mathrm{a}}$ Transformants were grown for 4 weeks on M-SC medium without antibiotics. Fifty colonies were tested for resistance to the antibiotic originally used to select the transformant and for light production measured in a scintillation counter. but tetracycline sensitive and blue on X-gal/isopropyl $\beta$-D-thiogalactoside plates were tested by restriction analysis using BamHI to confirm insertion of the kanamycin-resistance gene into the tetracycline-resistance gene of pLAFR5 (Keen et al. 1988).

\section{Transformation and transposon mutagenesis.}

Plasmids were introduced into Lxx by electroporation (BioRad, Hercules, CA, U.S.A.) using a modification of the method of Lampel and associates (1994). Lxx cells were diluted with $400 \mu \mathrm{l}$ of ice cold S8 broth immediately after voltage application $(100 \Omega, 125 \mu \mathrm{F}, 2.5 \mathrm{kV})$ and were then spread onto nitrocellulose membranes $(0.22 \mu \mathrm{m}$ Metricel CN $70 \mathrm{~mm}$; Gelman Sciences, Ann Arbor, MI, U.S.A.) placed on the surface of M-SC plates. After approximately $72 \mathrm{~h}$ of incubation at $28^{\circ} \mathrm{C}$, the membranes were transferred to M-SC plates containing tetracycline $(10 \mu \mathrm{g} / \mathrm{ml})$, kanamycin or streptomycin $(50$ $\mu \mathrm{g} / \mathrm{ml})$, or ampicillin $(100 \mu \mathrm{g} / \mathrm{ml})$, depending on the introduced plasmid.

\section{Stability studies.}

Various Lxx transformants were grown in S8 broth containing the appropriate antibiotics, and the cells were then washed three times with sterile distilled water to remove any residual antibiotic. Approximately $300 \mathrm{CFU}$ in $200 \mu \mathrm{l}$ were then spread onto M-SC plates containing no antibiotics. After 4 to 5 weeks, 50 individual colonies of each transformant were replica-plated onto M-SC plates with and without the appropriate antibiotics and, after 4 to 5 weeks, the number of viable colonies was counted.

\section{Light production.}

Lxx::Tn4431 mutants were initially assessed for light production using an AT1 imaging system (Wright Instruments Ltd., Enfield, England). Subsequent measurements were taken by growing the Lxx transformants for 12 days in $10 \mathrm{ml}$ of S8 broth containing $5 \mu \mathrm{g}$ of tetracycline per $\mathrm{ml}$, pelleting the cells by centrifugation $(6000 \times g$ for $5 \mathrm{~min})$ and measuring the light production in a $500 \mu \mathrm{l}$ aliquot of the culture supernatant using a Packard 1500 Tri-Carb liquid scintillation counter (Packard Bioscience Co., Meriden, CT, U.S.A.) with the coincidence monitor turned off. To increase luminescence from weak samples, $1 \mu$ of n-decyl-aldehyde (Sigma, St. Louis) was placed on the inside surface of a petri dish lid or eppendorf lid (neither in contact with the colonies nor in the liquid medium).

\section{PCR analysis.}

For PCR analysis of the transformants, cells were picked from actively growing colonies. These cells were mixed with the PCR reaction mix $\left(2.5 \mu \mathrm{M} \mathrm{Mg}^{2+}, 0.5 \mathrm{U}\right.$ Taq polymerase, 10 ng primer, $0.2 \mu \mathrm{M}$ dNTPs in a final volume of $25 \mu \mathrm{l}$ ) and amplified in a Perkin Elmer 480 thermocycler (Perkin Elmer, Shelton, CT, U.S.A.) for $5 \mathrm{~min}$ at $94^{\circ} \mathrm{C}$, followed by 30 cycles with an annealing temperature of $55^{\circ} \mathrm{C}$. The forward and re-

Table 3. Stability of Lxx::Tn4431 mutants ${ }^{\mathrm{a}}$

\begin{tabular}{lccc}
\hline Mutant & Plasmid & $\begin{array}{c}\text { \% of Antibiotic } \\
\text { colonies }\end{array}$ & $\begin{array}{c}\text { \% of Luminescent } \\
\text { colonies }\end{array}$ \\
\hline 134 & pUCD623 & 100 & 100 \\
$253 \mathrm{~A}$ & pUCD623 & 100 & 96 \\
282 & pUCD623 & 84 & 66 \\
362 & pUCD623 & 100 & 73 \\
476 & pUCD623 & 100 & 88 \\
995 & pUCD623 & 100 & $\mathrm{~N} / \mathrm{t}^{\mathrm{b}}$ \\
\hline
\end{tabular}

${ }^{a}$ Mutants were grown for 4 weeks on M-SC medium without antibiotics.

${ }^{\mathrm{b}} \mathrm{N} / \mathrm{t}=$ Not tested. 
verse primer sequences for PCR amplification of the nptII region of the various plasmids were CAAGATGGATTGCACGCAGGT (Tn5 160 to 180) and CGATACCGTAAAGCACGAGGA (Tn5 889 to 869), respectively.

To test for the presence of suicide vector pUCD623 in the various Lxx::Tn4431 mutants, PCR primers were designed to the chloramphenicol acetyltransferase (CAT) and $\beta$-lactamase (bla) genes, both encoded on pUCD623 outside of Tn4431. However, because no sequence data was available for the pUCD623 CAT or bla genes, primers were designed from pCAT-Basic and pBR322, respectively. The primer sequences were as follows: CAT, cat $15^{\prime}$-GGAGAAAAAATCACTGGATATACC-3', cat2 5'-GAAGTTGTCCATATTGGCCA-3'; and bla, apr1 5'-TTACCAATGCTTAATCAGTG-3', apr2 5'-TTTAAAGTTCTGCTATGTGG-3'. DNA was amplified with either cat 1 and cat 2 primers or apr1 and apr2 primers in a $1 \times$ PCR Master Mix buffer (Promega, Madison, WI, U.S.A.) according to the manufacturer's instructions. Reactions were performed in an MJ Research PTC-100 thermal cycler (MJ Research Inc., Waltham, MA, U.S.A.) for 30 cycles and with primer annealing temperatures of $50^{\circ} \mathrm{C}$ (CAT primers) or $45^{\circ} \mathrm{C}$ (bla primers).

\section{Sequence analysis.}

Tn4431 was subcloned in the EcoRI/Pst I site in pBLUESCRIPT (Stratagene, La Jolla, CA, U.S.A.) and the EcoRI end was sequenced using the T7 primer. The sequence was analyzed for potential promoter regions using the Neural Network Promotor Predictor (1998 version) of the Berkeley Drosophila Genome Project (Waibel et al. 1989; Reese and Eeckman 1995).

\section{ACKNOWLEDGMENTS}

We thank the Sugar Research and Development Corporation for providing part of the funding for this research. We also thank R. Murphy for primer design and PCR testing of Lxx::Tn4431 mutants for the presence of vector sequences.

\section{LITERATURE CITED}

Bailey R. A. 1977. The effect of hot water treatment, ratoon stunting disease, and moisture stress on the incidence of smut in sugarcane. Proc. Int. Soc. Sugar Cane Technol. 16:327-335.

Comstock, J. C., Miller, J. D., and Tai, P. Y. P. 1998. Development of ratoon stunting disease resistant sugarcane clones in Florida. Abstract 3.4.49 in: Proc. of RSD Conf. Workshop Int. Congr. of Plant Pathol., 7th. Int. Soc. Plant Pathol., Edinburgh, Scotland.

Croft, B. J. and Greet, A. J. 1997. A simple method of rating sugarcane cultivars for resistance to ratoon stunting disease. In: Proc. Int. Soc. Sugar Cane Technologists Pathol. and Mol. Biol. Workshop. Int. Soc. Sugar Cane Technol. Durban, South Africa.

Croft, B. J. and Smith G. R. 1995. Major diseases affecting sugarcane production in Australia and recent experiences with sugarcane diseases in quarantine. Pages 55-58 in: Sugarcane Germplasm Conservation and Exchange. Austr. Cent. Int. Agric. Res. Proc. No. 67. B. J. Croft, C. M. Piggin, E. S. Wallis, and D. M. Hogarth, eds. Australian Centre for International Agricultural Research, Canberra, ACT, AU.

Davis, M. J. 1980. Ratoon stunting disease of sugarcane: Isolation of the causal bacterium. Science 210:1365-1367.

Davis, M. J., Gillaspie A. G., Vidaver, A. K., and Harris, R. W. 1984. Clavibacter: A new genus containing some phytopathogenic coryneform bacteria, including Clavibacter xyli subsp. xyli sp. nov., subsp. nov. and Clavibacter xyli subsp. cynodontis. subsp. nov., pathogens that cause ratoon stunting disease of sugarcane and bermuda grass stunting disease. Int. J. Syst. Bacteriol. 34:107-117.

D’Hont, A., Lu, Y. H., González de León, D., Grivet, L., and Feldmann, P. 1994. A molecular approach to unraveling the genetics of sugarcane, a complex polyploid of the Andropogoneae tribe. Genome 37:222230 .

Evtushenko, L. I., Dorofeeva, L. V., Subbotin, S. A., Cole, J. R., and Tiedje, J. M. 2000. Leifsonia poae gen. nov., sp. nov., isolated from nematode galls on Poa annua, and reclassification of 'Corynebacte- rium aquaticum' Leifson 1962 as Leifsonia aquatica (ex Leifson 1962) gen. nov., nom. rev., comb. nov. and Clavibacter xyli Davis et al. 1984 with two subspecies as Leifsonia xyli (Davis et. al. 1984) gen. nov., comb. Nov. Int. J. Syst. Evol. Microbiol. 50:371-380.

Gillaspie, A. G., Davis, R. E., and Worley, J. F. 1973. Diagnosis of ratoon stunting disease based on the presence of a specific microorganism. Plant Dis. Rep. 57:987-990.

Gillaspie, A. G., and Teakle, D. S. 1989. Ratoon stunting disease. Pages 59-80 In: Diseases of Sugarcane; Major Diseases. C. Ricaud, B. T. Egan, A. G. Gillaspie, Jr., and C. G. Hughes, eds. Elsevier Science Publishing, Inc., New York.

Haynes, J. A. and Britz, M. L. 1989. Electrotransformation of Brevibacterium-lactofermentum and Corynebacterium-glutamicum - growth in tween 80 increases transformation frequencies. FEMS (Fed. Eur. Microbiol. Soc.) Letters 61:329-334.

Hughes, C. G. 1974. The economic importance of ratoon stunting disease. Pages 213-217 in: Proc. Congr. Int. Soc. of Sugar Cane Technologists, 15th. J. Dick and D. J. Collingwood, eds. Int. Soc. Sugar Cane Technol. Durban, South Africa.

Keen, N. T., Tamaki, S., Kobayashi, D., and Trollinger, D. 1988. Improved broad-host-range plasmids for DNA cloning in gram-negative bacteria. Gene 70:191-197.

Lampel, J. S., Canter, G. L., Dimock, M. B., Kelly, J. L., Anderson, J. J., Uratani, B. B., Foulke, J. S. J., and Turner, J. T. 1994. Integrative cloning, expression and stability of the cryIA(c) gene from Bacillus thuringiensis subsp. kurstaki in a recombinant strain of Clavibacter xyli subsp. cynodontis. Appl. Environ. Microbiol. 60:501-508.

Maramorosch, K., Plavsic-Banjac, B., Bird, J., and Liu, L. J. 1973. Electron microscopy of ratoon stunted sugar cane: Microorganisms in xylem. Phytopathol. Z. 77:270-273.

Meletzus, D., Bermpohl, A., Dreier, J., and Eichenlaub, R. 1993. Evidence for plasmid-encoded virulence factors in the phytopathogenic bacterium Clavibacter michiganensis subsp. michiganensis NCPPB382. J. Bacteriol. 175:2131-2136.

Metzler, M. C., Zhang, Y.-P., and Chen, T.-A. 1992. Transformation of the gram-positive bacterium Clavibacter xyli subsp. cynodontis by electroporation with plasmids from the IncP incompatibility group. J. Bacteriol. 174:4500-4503.

Mudge, S. R., Lewis-Henderson, W. R., and Birch, R. G. 1996. Comparison of Vibrio and firefly luciferases as reporter gene systems for use in bacteria and plants. Aust. J. Plant Physiol. 23:75-83.

Reese, M. G., and Eeckman, F. H. 1995. New neural network algorithms for improved eukaryotic promoter site recognition. 7th Int. Genome Sequencing and Anal. Conf. Hilton Head SC. Genome Science and Technol. 1:45.

Roach, B. T. 1987. Observations on the incidence, effects, and control of ratoon stunting disease. Proc. Austr. Soc. Sugar Cane Technol. 9:109116.

Sambrook, J., Fritsch, E. F., and Maniatis, T. 1989. Molecular Cloning: A Laboratory Manual. 2nd ed. Cold Spring Harbor Laboratory Press, Cold Spring Harbor, N.Y., U.S.A.

Schäfer, A., Kalinowski, J., Simon, R., Seep-Feldhaus, A.-H., and Pühler, A. 1990. High-frequency conjugal plasmid transfer from gram-negative Escherichia coli to various gram-positive coryneform bacteria. J. Bacteriol. 172:1663-1666.

Shaw, J. J., Settles, L. G., and Kado, C. I. 1988. Transposon Tn4431 mutagenesis of Xanthomonas campestris pv. campestris: Characterization of a nonpathogenic mutant and cloning of a locus for pathogenicity. Mol. Plant-Microbe Interact. 1:39-45.

Simon, R., Priefer, U., and Pühler, A. 1983. A broad host range mobilization system for in vivo genetic engineering: Transposon mutagenesis in gram-negative bacteria. Biotechnol. 1:784-791.

Staskawicz, B., Dahlbeck, D., Keen, N., and Napoli, C. 1987. Molecular characterization of cloned avirulence genes from Race 0 and Race 1 of Pseudomonas syringae pv syringae. J. Bacteriol. 169:5789-5794.

Steindl, D. R. L. 1974. Ratoon stunting disease history, distribution, and control. Pages 210-212 in: Proc. Congr. Int. Soc. Sugar Cane Technol, 15th. J. Dick and D. J. Collingwood, eds. Int. Soc. Sugar Cane Technol. Durban, South Africa.

Suzuki, K.-I., Suzuki, M., Sasaki, J., Park, Y.-H., and Komagata, K. 1999. Leifsonia gen. nov., a genus for 2,4-diaminobutyric acid-containing actinomycetes to accommodate "Corynebacterium aquaticum" Leifson 1962 and Clavibacter xyli subsp. cynodontis Davis et al. 1984. J. Gen. Appl. Microbiol. 45:253-262.

Taylor, P. W. J., Ryan, C. C., and Birch, R. G. 1988. Harvester transmission of leaf scald and ratoon stunting disease: Demonstration and evaluation of methods for decontamination. Sugar Cane 4:11-14.

Taylor, J., Stearman, R. S., and Uratani, B. B. 1993. Development of a native cloning vector in Clavibacter xyli subsp. cynodontis. Plasmid 29:241-244. 
Teakle, D. S., and Ryan, C. C. 1992. The effect of high temperature on the sugar cane ratoon stunting disease bacterium, Clavibacter xyli subsp. xyli, in vitro and in vivo. Sugar Cane 6:5-6.

Teakle, D. S., Smith, P. M., and Steindl, D. R. L. 1973. Association of a small coryneform bacterium with the ratoon stunting disease of sugarcane. Aust. J. Agric. Res. 24:869-874.

Vertès, A. A., Inui, M., Kobayashi, M., Kurusu, Y., and Yukawa, H. 1993. Presence of $m r r$ - and $m c r$-like restriction systems in coryneform bacte- ria. Res. Microbiol. 144:181-185.

Victoria, J. F., Ochoa, O., and Cassale, H. C. 1986. Thermic control of ratoon stunting disease of sugarcane in Colombia. Proc. Int. Soc. Sugar Cane Technol. 19:325-331.

Waibel, A. H., Hanazawa, T., Hinton, G. E., Shikano, K., and Lang, K. J. 1989. Phoneme recognition using time-delay neural networks. IEEE (Inst. Electr. Electron. Eng.) Trans. Acoust. Speech Signal Processing 37:328-339. 